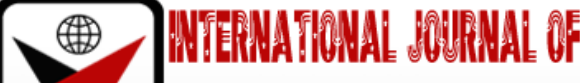

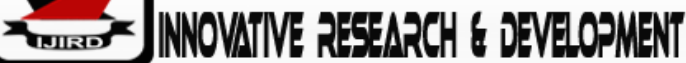

ISSN $2278-0211$ (Online)

\section{Relationship between Teacher's Level of Training in Information Communication and Technology and Students' Academic Achievement in Physics in Makueni County, Kenya}

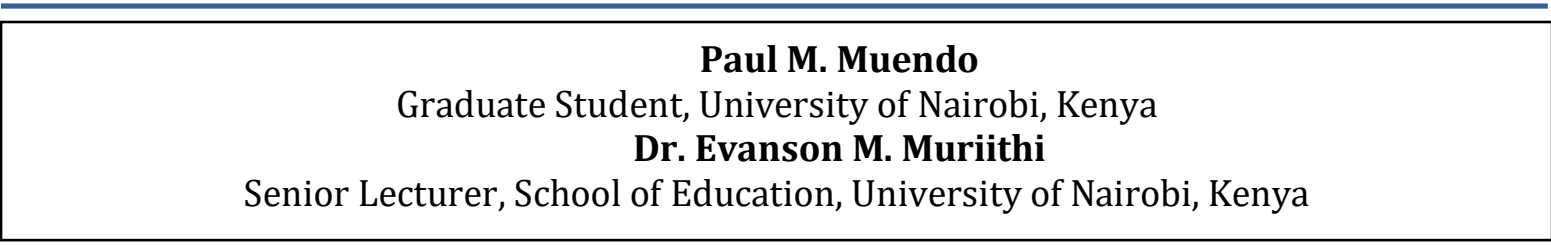

\begin{abstract}
:
Recent studies have found out that the use of Information communication and Technology (ICT) in teaching makes learning enjoyable thereby leading to improvement of academic achievement by the learner. Teachers who have high ICT skills have been found to demonstrate high levels of competency in using ICT in teaching. To get sufficient skills in the use of ICT, one has to undergo training or get exposed to the use of ICT through interaction with peers or through self-learning on the internet. This study sought to investigate the relationship between teacher's level of ICT training and how it influences a learner's academic achievement in physics in Makueni County. Stratified random sampling was applied to select a sample of 60 schools from a total population of 375 schools. The research used descriptive survey design where participants answered questions administered through interviews and questionnaires. Microsoft (MS) Excel (2010) was used to analyze the data. The objectives were analyzed through descriptive statistics and conceptual content analysis whereas analysis of variance (ANOVA) was used to test the hypotheses. From the study, it was observed that students taught by teachers who trained ICT from an ICT training college obtained higher scores than students taught by teachers who took ICT as a unit in teacher training colleges. It was also observed that students taught by teachers with high levels of ICT training obtained a high means core than students taught by teachers with low level of ICT training. However, the study found out that students taught by teachers who were trained to use physics software produced students with low mean score than teachers who were not trained to use any physics software. From the findings, it was concluded that the teacher's level of ICT training affects student's academic achievement in physics with teachers who have high level of ICT training producing students who have a higher performance than students taught by teachers with low level of ICT training. From these findings, it was recommended that ICT training centers which specialize in training teachers be established, the ministry of education to organize more frequent in-service training (INSET) programs to enable teachers acquire more ICT skills and lastly, more research to be done on the influence physics software's have on the academic achievement of students in physics.
\end{abstract}

Keywords: Physics, information communication and technology, training, academic achievement

\section{Introduction}

A students' learning achievement can be seen in the grades the student scores in an assessment within the learning process. In Kenya, students are issued with a national examination after their four years in secondary school and their performance is used to place them in institutions of higher learning (Musasia, Abacha and Biyoyo, 2012). The national performance in physics has been low as observed by Mulambe (2017). A research by Muindi (2015) showed performance by students in physics has persistently been poor in Makueni County.

Student achievement in physics is affected by several factors. Some of the major factors which affect achievement in physics among students in secondary schools as identified in a study by Wachira (2014), are student characteristics such as their career goals, attitude towards the subject and their gender, school environment such as availability of wellequipped laboratories and teacher characteristics which include missing classes their relationship with students and their methods of teaching, which include use of ICT in teaching.

To attain ICT skills and hence develop high competency levels on technology use in teaching, teachers should attend training courses on ICT integration in teaching and learning settings. According to Ghavifekr \& Rosdy (2015), professional development and training programs for teachers play a key role in enhancing students' quality learning. Many schools however prefer peer tutoring programs where a more skillful teacher in ICT assists another teacher who is less experienced on ICT matters (Ghavifekr \& Rosdy, 2015). In a study by Munanu (2014), it was observed that computer training influenced a teacher's readiness to use ICT in teaching. Training would enable the teacher acquire more knowledge, make the teacher more confident on ICT use and thereby ensuring faster coverage of the syllabus. 
In other studies, it was observed that most teachers have the ability and training to use computers but their ICT skills are not well advanced. Goko (2012), conducted a research on factors affecting the use of information and communication technology in teaching and learning in secondary schools in Kangema- Murang'a County, and observed that $85.4 \%$ of the teachers have certificate in computer application packages while only $4.2 \%$ had a diploma in ICT while $10.4 \%$ did not disclose the level of ICT training.

Professional development courses for teachers help them to improve their ICT skills and knowledge. However, Abuhmaid (2010), highlighted challenges regarding the conduct and the nature of these courses including teachers believes, timing and modes of training, workload, follow-up, motivation and school culture. Computer training enables teachers to acquire more knowledge which in turn makes them more confident and improves their competency on ICT use thus, there is need to have regular refresher courses (Abuhmaid, 2010). In a study by Munanu (2014), on factors influencing teacher's readiness to use ICT in teaching in public secondary schools in Gatundu north district, Kiambu County, Kenya, all the respondents indicated that computer training influence a teacher's readiness to use ICT in teaching.

\subsection{Purpose}

The main purpose of this study was to compare the relationship between teacher's level of training in ICT and students' academic achievement in physics in Makueni County in Kenya.

Research Objectives

\subsection{The Objectives of the Study Were}

- To investigate the relationship between mean score of students taught by teachers who took ICT as a unit in teacher training college and teachers who majored in ICT training in colleges.

- To investigate the relationship between means core of students taught by teachers who are trained to use physics application software and those who are not trained to use physics software.

- To investigate the relationship between means core of students taught by teachers with high level of ICT training and teachers with low level of ICT training.

\subsection{Research Hypotheses}

The following null hypotheses were tested in the study.

- There is no statistical significant difference between the means core of students taught by teachers who took ICT as a unit in teacher training college and teachers who majored in ICT training in colleges.

- There is no statistical significant difference between the means core of students taught by teachers who are trained to use physics application software and those who are not trained to use physics software.

- There is no statistical significant difference between the means core of students taught by teachers with high level of ICT training and teachers with low level of ICT training.

\section{Methodology}

This study used descriptive survey design where participants answered questions administered through interviews and questionnaires. Microsoft (MS) Excel (2010) was used to analyze the data. The objectives were analyzed through descriptive statistics and conceptual content analysis whereas analysis of variance (ANOVA) was used to test the hypotheses at 0.05 level of significance. The $\mathrm{F}$ value calculated was compared against the critical $\mathrm{F}$ value and the $\mathrm{P}$ value obtained compared to the level of significance. When the F value obtained was greater than the critical $\mathrm{F}$ value, then the hypothesis was rejected implying that there was significant difference between the variables under investigation. Similarly, if the p-value obtained was less than the level of significance then, the null hypothesis was rejected and the alternate one accepted.

\section{Findings and Discussions}

\subsection{Teacher's Level of ICT Training}

Training is essential to acquaint one with competency skills in ICT. According to Munanu (2014), ICT training enables the teacher to acquire more confidence on ICT use. From the teachers studied, $82 \%$ admitted to have had a formal training in ICT. 30\% of them took computer studies at KCSE level, 48\% took ICT as a unit in teacher training colleges, and $42 \%$ have a certificate in ICT from an ICT college while 3\% have a diploma in ICT training. These results were similar with results from an earlier research done by Goko (2012) who observed that $85.4 \%$ of the teachers had certificate in computer studies but only $4.2 \%$ had a diploma in ICT. This implies that most physics teachers have some level of competence in the use of ICT but lack advanced skills that may be necessary when teaching the subject at secondary school level. This study also found out that there is no respondent who has an undergraduate or post graduate training in ICT. The breakdown in percentage is shown in Table one below. 


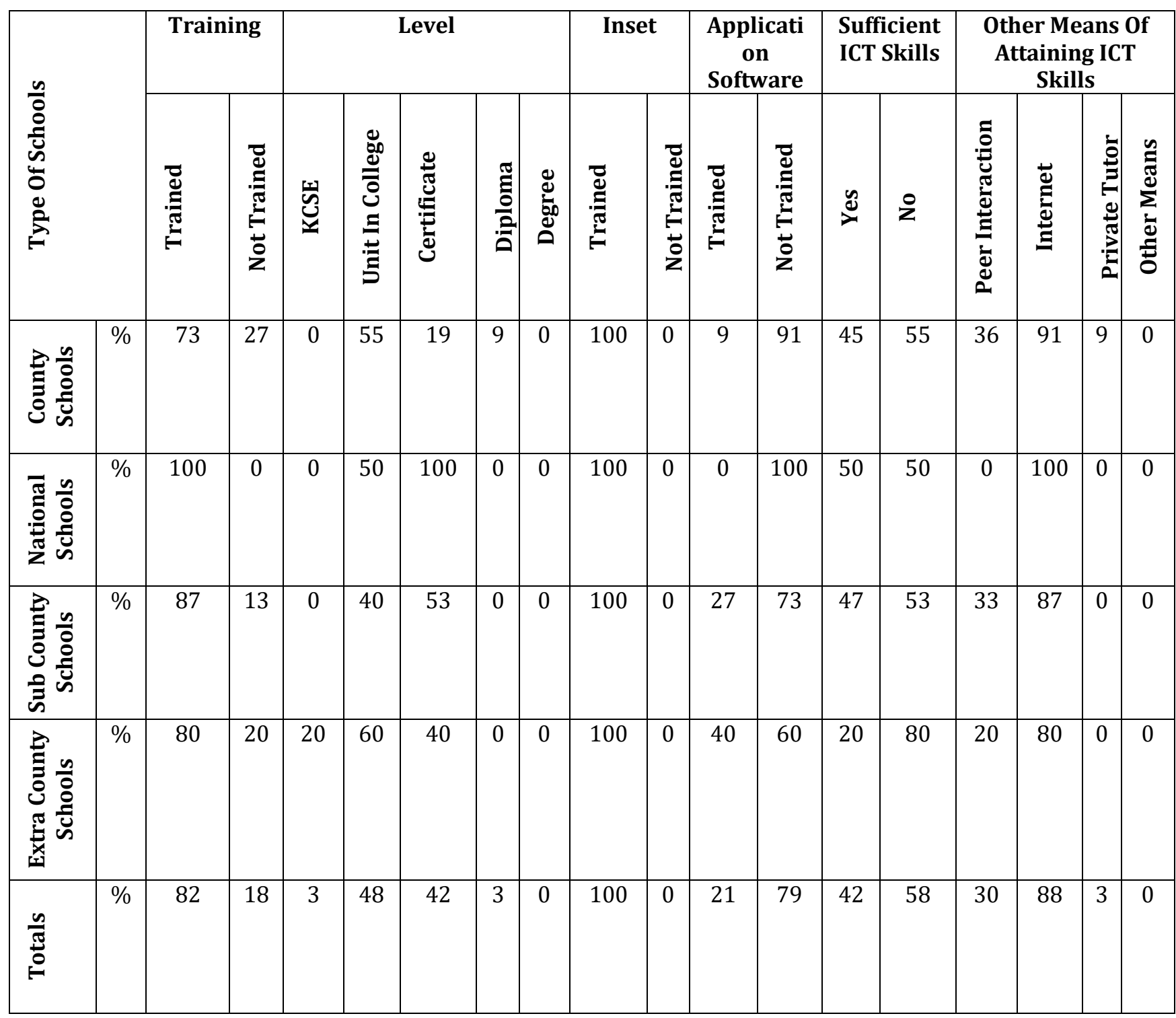

Table 1: Teacher Training In the Use of ICT in Teaching Physics

From Table 1, only 20\% of teachers in Extra County schools took ICT at KCSE. 50\% of respondents in national schools, $60 \%$ in Extra County, 55\% in County and $40 \%$ in sub county schools took ICT as a unit in teacher training colleges. In addition, all teachers in national schools, $60 \%$ in extra county schools, $19 \%$ in County schools and $53 \%$ in Sub county schools have a certificate in ICT training from an ICT college while only $9 \%$ of teachers in county Schools had a diploma in ICT training. This shows that majority of the teachers (48\%) have their ICT training at teacher training colleges where they took ICT as a unit.

The respondents were also asked if they have attended any in-service training (INSET) which emphasized on the use of ICT in teaching physics. These INSETS are conducted by CEMASTEA and SMASSE. All respondents admitted to have attended such trainings. The duration of attendance varied with the least being one week and the most being 6months. From the literature review, it was found out that regular refresher courses are important since they enable teachers acquire more knowledge which in turn makes them more confident and improves their competency. It thus becomes important to have more in-service trainings as one principal interviewed said;

'When teachers got trained through SMASSE, they are able to deliver their content in multiple ways and involve the learners more making learning more real and interactive'.

To get more information on ICT training, the respondents were asked if they have been trained on any application software used for teaching physics and only $27 \%$ in sub county schools, $40 \%$ in extra county schools and $9 \%$ in county schools admitted to have been trained. This transforms to only $21 \%$ of the respondents having training on any application software for teaching physics. However, $12 \%$ of the respondents cited Google classroom as the software they had been trained on. This software does not just specialize in teaching physics and this leaves only $9 \%$ to have been trained on using physics software. The software's which they cited were circuit maker, Encarta and phet Colorado.

The other avenues studied as a source of acquiring ICT knowledge and skills include interaction with peers, internet and private tutors in whom $88 \%$ of the respondents admitted to have acquired ICT skills from the internet making it the largest channel through which teachers studied acquired ICT skills. $30 \%$ of respondents admitted to have acquired ICT skills through interaction with peers with only $3 \%$ citing to have used a private tutor to acquire ICT skills. The findings 
confirm with earlier findings in the literature review in which more teachers prefer peer tutoring programs where a more skilled teacher in ICT assists another teacher who is less experienced (Ghavifekr and Rosdy, 2015).

The respondents were asked on their opinion on the sufficiency of ICT skills they feel they have acquired from their various trainings and exposure on ICT learning. Only 42\% of them said they have acquired sufficient skills to integrate ICT in teaching physics where 50\% came from national school, $20 \%$ in Extra County, $45 \%$ in the county and $47 \%$ in the sub county schools. However, the largest percentage, 58\% of the respondents said they have not acquired sufficient skills to integrate ICT in teaching physics. These findings concur to earlier observations made by Munanu (2014) where he stated that most teachers have the ability and training to use computers but their ICT skills are not well advanced. It thus can be observed that in order to boost teacher's ICT skills, there is need to increase the frequency of in-service trainings.

The researchers wanted to find out from the respondents if there was any institution offering ICT training to physics teachers. Majority of the respondents said they don't know of any institution while the few who admitted to knowing one cited SMASSE and CEMASTEA. These bodies specialize on strengthening science subjects and thus it's clear there is need for an institution which offers ICT training to teachers.

From the study, there are some challenges and weaknesses which were highlighted by teachers regarding ICT training. These include lack of enough ICT equipment in schools, frequency of in-service trainings being scanty and lack of attitude/interest in some teachers. These findings corresponded with other findings by Abuhmaid (2010) who highlighted challenges to ICT training to teachers which include teacher believe, timing, mode of training and workload.

\subsection{Relationship between Teacher's Level of ICT Training and Students' Academic Achievement in Physics}

To investigate the relationship between teacher's level of ICT training and students' academic achievement in physics, document sheets were issued to the respondents who were required to fill the KCSE physics test results for the past 4 years. The KCSE exam results were chosen since the exam is tested and done uniformly throughout the country thus providing a common ground for analyzing the student results. The mean mark for the four years was then calculated and tabulated.

\begin{tabular}{|c|c|c|c|c|c|c|c|c|}
\hline & \multicolumn{2}{|c|}{ ICT Trained } & \multicolumn{2}{c|}{ Level of ICT Training } & \multicolumn{2}{c|}{$\begin{array}{c}\text { Trained on } \\
\text { Application } \\
\text { Software }\end{array}$} & $\begin{array}{c}\text { Acquired Sufficient } \\
\text { ICT Skills }\end{array}$ \\
\hline & Trained & $\begin{array}{c}\text { Not } \\
\text { Trained }\end{array}$ & $\begin{array}{c}\text { KCSE/Unit } \\
\text { in College }\end{array}$ & $\begin{array}{c}\text { Certificate } \\
\text { /Diploma }\end{array}$ & Trained & $\begin{array}{c}\text { Not } \\
\text { Trained }\end{array}$ & Yes & No \\
\hline $\begin{array}{c}\text { National } \\
\text { Schools }\end{array}$ & 8.41 & 7.5 & 7.96 & & 8.41 & 7.5 & 8.41 \\
\hline $\begin{array}{c}\text { Extra } \\
\text { CountyScho } \\
\text { ols }\end{array}$ & 7.1 & 5.5 & 7.1 & 7.05 & 7.0 & 6.6 & 7.3 & 6.65 \\
\hline $\begin{array}{c}\text { CountyScho } \\
\text { ols }\end{array}$ & 5.36 & 4.67 & 5.17 & 5.7 & 4.87 & 5.2 & 5.88 & 4.58 \\
\hline $\begin{array}{c}\text { Sub county } \\
\text { Schools }\end{array}$ & 3.79 & 2.25 & 3.34 & 4.04 & 3.85 & 3.3 & 3.68 & 3.73 \\
\hline $\begin{array}{c}\text { Average } \\
\text { mean mark }\end{array}$ & 6.165 & 4.14 & 5.7775 & 6.1875 & 5.24 & 5.8775 & 6.09 & 5.842 \\
\hline
\end{tabular}

Table 2: Mean Mark for Schools at the Various Levels of ICT Training

From Table 1, the average means core for students taught by teachers who are trained on using ITC is 6.165 and the means core of students taught by teachers with no ICT training is 4.14. This shows that ICT training of teachers contributed positively to the general performance of students in physics. This observation can be attributed to the findings from earlier studies that a teacher trained in ICT use is more competent to use ICT in teaching which leads to improvement of learner scores. It is also observed that the mean score of students taught by teachers who have a certificate and diploma in ICT training is 6.1875 which is higher than 5.7775 , the means core of students taught by teachers who took ICT as a unit in teacher training college. These results support the notion that a higher level of ICT training makes a teacher more confident and competent to use ICT in teaching and thereby lead to production of higher student scores.

On the contrary, students taught by teachers who are trained in using a physics software obtained a mean score of 5.8775 which is lower than 5.24, the mean score obtained by students taught by teachers who have no training on using physics software. From the results obtained, it can be concluded that a teacher's training on using physics software does not necessarily lead students to perform well. This can be attributes to the fact that most teachers don't use the physics software in teaching.

From table 1, it can be observed that students taught by teachers who have sufficient ICT skills obtained a mean score of 6.09 which was better than 5.842, the mean score obtained by students taught by teachers without sufficient ICT skills. It thus can be concluded that teachers with sufficient ICT skills use ICT more effectively in teaching and thereby make learners to achieve high scores. 
3.3. Relationship between Mean Score of Students Taught by Teachers Who Took ICT as a Unit in Teacher Training College and Teachers Who Trained ICT from ICT Training Colleges

From Table 2, the students taught by teachers with Certificate and diploma in ICT training obtained a mean score of 6.1875 which was better than the mean score of students taught by teachers who took ICT as a unit in teacher training college and had KCSE certificate in ICT who had a mean score of 5.7775. This implies that the level of training of teachers has an influence on students' performance. To check if there is any statistical significant difference in the mean scores, the following null hypothesis was test through analysis of variance.

- H01: There is no statistical significant difference between the means core of students taught by teachers who took

ICT as a unit in teacher training college and teachers who majored in ICT in training colleges

To test the hypothesis, ANOVA was carried out using MS Excel and the results tabulated in Table 3.

\begin{tabular}{|c|c|c|c|c|c|c|}
\hline $\begin{array}{c}\text { Source of } \\
\text { Variation }\end{array}$ & SS & df & MS & F & P-value & F crit \\
\hline Between Groups & 19.60525 & 3 & 6.535083 & 53.07682 & 0.001117 & 6.591382 \\
\hline Within Groups & 0.4925 & 4 & 0.123125 & & & \\
\hline Total & 20.09775 & 7 & & & & \\
\hline
\end{tabular}

Table 3: ANOVA Analysis for Mean Score of Students Taught by Teachers Who Trained ICT from

Teacher Training College and Teachers Who Trained ICT from ICT Training Colleges

From Table 3, the F value obtained is 53.077 and is greater than the critical value of $\mathrm{F}$ which is 6.59. Similarly, the $\mathrm{P}$ value obtained of 0.00117 is les that the level of significance which is 0.05 and thus the null hypothesis that there is no statistical significant difference between the mean score of students taught by teachers who took ICT as a unit in teacher training college and teachers who trained ICT from ICT training colleges is rejected. The alternative is adopted meaning there is a statistical significant difference between scores of students taught by teachers who trained ICT at teacher training college and teachers who trained ICT from ICT training colleges. These findings show that a teacher who trained ICT from a higher level of ICT training obtained more skills which in turn made the teacher more competent on using ICT in teaching physics and thereby lead students to perform better. The findings concur with earlier research findings by Abuhmaid (2010) who observed that computer training enables teachers to acquire more knowledge which in turn makes them more confident and improves their competency on ICT use.

\subsection{Relationship between Means Core of Students Taught by Teachers Who Are Trained to Use Any Physics Application} Software and Those Who Are Not Trained to Use Physics Software

From Table 2, it is observed that the means core of students taught by teachers who have been trained to use physics software is 5.24. This mean score is slightly lower than the means core of students taught by teachers who have not been trained to use physics software who obtained a mean score of 5.8775. These scores imply that a teacher training in using physics software does not necessarily make students to perform better in physics. To check if there is any statistical significant difference in the scores, the following null hypothesis was tested.

- HO2: There is no statistical significant difference between the means core of students taught by teachers who are trained to use physics application software and those who are not trained to use physics software.

To test the hypothesis, Analysis of Variance was conducted on the two sets of scores and the results tabulated as shown in Table 4 below.

\begin{tabular}{|c|c|c|c|c|c|c|}
\hline $\begin{array}{c}\text { Source of } \\
\text { Variation }\end{array}$ & SS & df & MS & F & P-value & F crit \\
\hline Between Groups & 19.61567 & 3 & 6.538557 & 68.65828 & 0.002907 & 9.276628 \\
\hline Within Groups & 0.2857 & 3 & 0.095233 & & & \\
\hline Total & 19.90137 & 6 & & & & \\
\hline \multicolumn{7}{|c|}{ Table 4: ANOVA Analysis }
\end{tabular}

From Table 4, the F value obtained is 68.66 and is greater than the critical value of $F$ which is 9.28 . Similarly, the $\mathrm{P}$ value obtained is 0.0029 and is les that the level of significance which is 0.05 . This implies that the null hypothesis that there is no statistical significant difference between the mean score of students taught by teachers who are trained to use any physics application software and those who are not trained to use physics software is rejected and the alternative adopted that there is a statistical significant difference between the mean score of students taught by teachers who are trained to use any physics application software and those who are not trained to use physics software. These findings on teacher training to use physics software do not concur with previous research which showed that computer training influenced a teacher's readiness to use ICT in teaching (Munanu, 2014) which in turn leads to improvement in student academic achievement.

\subsection{Relationship between Mean Score of Students Taught by Teachers with High Level of ICT Training and Teachers with Low Level of ICT Training}

The training level in ICT was divided into low level and high level. Those who took ICT at KCSE and as a unit in teacher training colleges were combined with those who did not have any training in application software and formed the 
low level of ICT training while those who had a certificate and diploma were combined with those who were trained in usage of application software to form the high level of ICT training. The mean sores for the low level were compared with those for the high level in the various categories of schools.

\begin{tabular}{|c|c|c|c|c|c|}
\hline & National & Extra county & County & Sub county & Average \\
\hline High level & 7.5 & 7.025 & 5.29 & 3.94 & 5.94 \\
\hline Low level & 7.95 & 6.85 & 5.19 & 3.34 & 5.83 \\
\hline
\end{tabular}

Table 5: Combined K.C.S.E Physics Mean Mark for Students Taught by Teachers with High Level and Low Level of ICT Training

From Table 5, Students from the Extra County, County and sub-County schools who were taught by teachers with a high level of training on ICT obtained a high mean mark than students taught by teachers who had a low level of training on ICT. On the contrary, students from the National schools who were taught by teachers with high level of training on ICT obtained low mean mark than students taught by teachers with low level of training on ICT. This is because on the National schools studied, there was no teacher who had training on using physics software and on this study, training on using physics software was categorized on the high level of ICT training.

The combined average mark of students taught by teachers with high level of ICT training was 5.94 which was higher than that of students taught by teachers with low level of ICT training which was 5.83. This shows that students taught by teachers with a high level of training on ICT understood physics concepts better leading to a better performance than students who were taught physics by teachers with a low level of training on ICT. To check if there is any statistical difference in the scores, the following null hypothesis was tested.

- HO3: There is no statistical significant difference between the means core of students taught by teacher with high level of ICT training and teachers with low level of ICT training.

Analysis of variance was conducted on the mean mark of students taught by teachers of both levels of ICT training. The results of the analysis are in Table 6 below.

\begin{tabular}{|c|c|c|c|c|c|c|}
\hline Source of Variation & SS & df & MS & F & P-value & F crit \\
\hline Between Groups & 19.89881 & 3 & 6.632936 & 87.98092 & 0.000416 & 6.591382 \\
\hline Within Groups & 0.301563 & 4 & 0.075391 & & & \\
\hline Total & 20.20037 & 7 & & & & \\
\hline
\end{tabular}

Table 6: ANOVA Analysis for High Level and Low-Level ICT Training Mean Marks

From Table 6, the p-value obtained was 0.000416 and is less than the alpha value, 0.05. Similarly, the F-value, 87.98 is greater than the critical $\mathrm{F}$ value, 6.59 thus the null hypothesis that there is no statistical significant difference between the teacher's level of ICT training and students' academic achievement in physics is rejected. This means there is a statistical significant difference between the teacher's level of ICT training and students' academic achievement in physics. It's also taken to imply that students taught by teachers with high level of ICT training perform better in physics than students taught by teachers with low level training in ICT. These findings concur with earlier findings by Ghavifekr and Rosdy (2015) who found out that professional development and training programs for teachers play a key role in enhancing student's quality learning.

When asked of their own opinion on the influence teacher's level of ICT training has on students' academic achievement in physics, all the principals and teachers strongly agreed that a high level of ICT training of teachers makes students perform better. To explain this opinion, one principal stated that ICT training makes a teacher pass physics content in an enjoyable simple method thereby demystifying the belief that physics is difficult. This makes the subject fun hence improving the performance of the students.

\section{Conclusion}

From the study, it was found out that those teachers with a high level of ICT training led students to obtain high scores in physics than teachers who had a low level of ICT training. It thus implies that the higher the level of ICT training a teacher has, the more the teacher acquires advanced ICT skills and make him more confident to integrate ICT effectively in the learning of physics. This makes the leaner enjoy learning the subject and in return the academic achievement of the learner improves.

\section{Recommendations}

The following recommendations are made from the findings and conclusion.

- ICT training centers which specialize in training teachers be established to train them on advanced ICT skills.

- The ministry of education should organize more frequent INSET programs to enable teachers acquire more ICT skills.

- More research should be done on the influence physics software's have on the academic achievement of students in physics. 


\section{References}

i. Abuhmaid, A., (2010). ICT Training Courses for Teachers Professional Development in Jordan. The Turkish Journal of Educational Technology, vol. 10 issue 4. East University Amman Jordan

ii. Ghavifekr, S.\&Rosdy, W.A.W. (2015). Teaching and learning with technology: Effectiveness of ICT integration in schools. International Journal of Research in Education and Science (IJRES), 1(2),175-191.

iii. Goko A.K (2012). Factors Affecting the Use of Information and Communication Technology in Teaching and Learning in Secondary Schools in Kangema- Murang'a County available on https://irlibrary.ku.ac.ke/bitstream/handle/123456789/5431/Goko\%20Alice\%20Karimi.pdf?sequence=3\&isAll owed=y

iv. Muindi J.M (2015). Investigating factors contributing to poor Performance in physics in KCSE by students in Secondary schools of Kathonzweni District; Makueni County. https://erepository.mku.ac.ke/handle/123456789/2355

v. Mulambe S.O (2017). School factors influencing the adoption of physics SMASSE teaching skills by physics Teachers in secondary schools in Kenya. American Scientific Research Journal for Engineering, Vol 35, No. 1

vi. Munanu L. C (2014). Factors Influencing Teachers Readiness To Use ICT In Teaching In Public Secondary Schools In Gatundu North District, Kiambu County, Kenya available on http://erepository.uonbi.ac.ke/bitstream/handle/11295/74186/

vii. Musasia, A.M., Abacha, O.A. and Biyoyo, M.E. (2012) Effect of Practical Work in Physics on Girls' Performance, Attitude Change and Skills Acquisition in the Form Two-Form Three Secondary Schools' Transition in Kenya. International Journal of Humanities and Social Sciences, 2, 151-166.

viii. Wachira W.M (2014). Factors affecting performance in physics among students in public secondary schools in Kiambu sub-county. https://erepository.mku.ac.ke/handle/123456789/2944 